\title{
Loss of Mecp2 in Substantia Nigra Dopamine Neurons Compromises the Nigrostriatal Pathway
}

\author{
Stephanie C. Gantz, ${ }^{1}$ Christopher P. Ford, ${ }^{2}$ Kim A. Neve, ${ }^{3}$ and John T. Williams ${ }^{1}$ \\ ${ }^{1}$ Vollum Institute, Oregon Health and Science University, Portland, Oregon 97239, ${ }^{2}$ Department of Physiology and Biophysics, Case Western Reserve \\ University, Cleveland, Ohio 44106, and ${ }^{3}$ Research Service, Department of Veterans Affairs Medical Center, Portland, Oregon 97239
}

Mutations in the methyl-CpG-binding protein 2 (MeCP2) result in Rett syndrome (RTT), an X-linked disorder that disrupts neurodevelopment. Girls with RTT exhibit motor deficits similar to those in Parkinson's disease, suggesting defects in the nigrostriatal pathway. This study examined age-dependent changes in dopamine neurons of the substantia nigra (SN) from wild-type, presymptomatic, and symptomatic Mecp $2^{+/-}$mice. Mecp2 ${ }^{+}$neurons in the SN in Mecp $2^{+/-}$mice were indistinguishable in morphology, resting conductance, and dopamine current density from neurons in wild-type mice. However, the capacitance, total dendritic length, and resting conductance of Mecp $2^{-}$neurons were less than those of Mecp $2^{+}$neurons as early as 4 weeks after birth, before overt symptoms. These differences were maintained throughout life. In symptomatic Mecp $2^{+/-}$mice, the current induced by activation of $\mathrm{D}_{2}$ dopamine autoreceptors was significantly less in Mecp2 $2^{-}$neurons than in Mecp $2^{+}$neurons, although $\mathrm{D}_{2}$ receptor density was unaltered in Mecp2 ${ }^{+/-}$mice. Electrochemical measurements revealed that significantly less dopamine was released after stimulation of striatum in adult $M e c p 2^{+/-}$mice compared to wild type. The decrease in size and function of Mecp2 $2^{-}$neurons observed in adult Mecp2 ${ }^{+/-}$mice was recapitulated in dopamine neurons from symptomatic Mecp $2^{-/ y}$ males. These results show that mutation in Mecp2 results in cell-autonomous defects in the SN early in life and throughout adulthood. Ultimately, dysfunction in terminal dopamine release and $\mathrm{D}_{2}$ autoreceptor-dependent currents in dopamine neurons from symptomatic females support the idea that decreased dopamine transmission due to heterogeneous Mecp2 expression contributes to the parkinsonian features of RTT in Mecp $2^{+/-}$mice.

\section{Introduction}

Rett syndrome (RTT) is an X-linked neurodevelopmental disorder occurring approximately once in 10,000 female births (Hagberg, 1985; Laurvick et al., 2006). A large majority of the affected females have mutations in the gene encoding the DNA binding protein, methyl-CpG-binding protein 2 (MeCP2) (Laurvick et al., 2006; Neul et al., 2008). The MECP2 gene resides on the $\mathrm{X}$-chromosome so that males with the mutation $\left(\mathrm{MECP}^{-/ y}\right)$, lack all functional MECP2 and usually die perinatally. Heterozygous (HET) females $\left(M E C P 2^{+/-}\right)$are mosaic for MeCP2 expression due to X-chromosome inactivation. Girls with RTT develop normally until 6-18 months of age, at which time they begin to regress and lose motor skills, particularly purposeful hand usage, ambulation, and postural control. In later stages, Parkinson-like symptoms including dystonia, festination, and inertia are often observed (Schanen, 1999; Chahrour and Zoghbi, 2007).

\footnotetext{
Received Feb. 8, 2011; revised June 29, 2011; accepted July 14, 2011.

Author contributions: S.C.G., C.P.F., K.A.N., and J.T.W. designed research; S.C.G. and C.P.F. performed research; K.A.N. contributed unpublished reagents/analytic tools; S.C.G., C.P.F., and K.A.N. analyzed data; S.C.G., C.P.F., and J.T.W. wrote the paper.

This work was supported by National Institutes of Health Grants DA026417 (C.P.F.), NS007466 (S.C.G.), and DK007680 (S.C.G.), the Department of Veterans Affairs, Veterans Health Administration, Office of Research and Development, Biomedical Laboratory Research and Development (K.A.N.), and the International Rett Syndrome Foundation (J.T.W.). We thank Drs. Gail Mandel and Dan Lioy for guidance and discussions.

Correspondence should be addressed to John T. Williams, Vollum Institute, L474, Oregon Health Sciences University, 3181 Southwest Sam Jackson Park Road, Portland, OR 97239. E-mail: williamj@ohsu.edu.

DOI:10.1523/JNEUROSCI.0684-11.2011

Copyright $\odot 2011$ the authors $\quad 0270-6474 / 11 / 3112629-09 \$ 15.00 / 0$
}

There are several Mecp2 mutant mouse models for RTT (Chen et al., 2001; Guy et al., 2001, 2007; Shahbazian et al., 2002; Guy et al., 2007). Both Mecp2 $2^{+/-}$and Mecp $2^{-/ y}$ mice develop a complex phenotype consistent with many features of the human disease, including compromised motor function. Similar to the human disease, Mecp $2^{+/-}$mice exhibit a delayed onset of behavioral symptoms and live significantly longer than $M e c p 2^{-1 y}$ mice (Chen et al., 2001; Guy et al., 2001; Viemari et al., 2005; McGill et al., 2006). Most studies have focused on Mecp $2^{-/ y}$ mice because the symptoms appear earlier and progress faster than in Mecp $2^{+/-}$mice. However, RTT is almost exclusively a female disease, so the Mecp $2^{+/-}$mouse may be a more appropriate genetic model.

In this study, dopamine (DA) neurons of the substantia nigra (SN) were examined because multiple lines of evidence suggest that they contribute to RTT pathology. In both RTT patients and Mecp 2 mutant mice, levels of biogenic amines are decreased and Parkinson-like motor deficits point to a disturbance of dopamine transmission (Wenk et al., 1991; Dunn and MacLeod, 2001; Panayotis et al., 2011). Conditional loss of Mecp2 from tyrosine hydroxylase-expressing catecholamine neurons has been associated with a reduction in locomotion in mice (Samaco et al., 2009). Furthermore, a recent report in $M e c p 2^{-/ y}$ mice found that SN neurons exhibit gradual alterations in morphology and function with the progression of motor impairments (Panayotis et al., 2011). However, the electrical properties and postsynaptic responses of dopamine neurons have not been studied. This study examined perturbations of dopamine neurons in the $M e c p 2^{+/-}$ 
mouse brain at ages before and after the appearance of motor symptoms. Mecp2 ${ }^{-}$dopamine neurons are smaller with a reduced dendritic arbor in both presymptomatic and symptomatic $M e c p 2^{+/-}$mice. In the $\mathrm{SN}$ of symptomatic mice, there is a selective decrease in the outward current induced by exogenous dopamine only in Mecp2 ${ }^{-}$neurons, with no change in the density of dopamine $\mathrm{D}_{2}$ receptors. Furthermore, in these animals the amount of dopamine released in the dorsal striatum is reduced. The results support the idea that decreased dopamine transmission due to heterogeneous expression of Mecp2 contributes to the parkinsonian features of RTT in Mecp $2^{+/-}$mice.

\section{Materials and Methods}

Animals. All studies were conducted in accordance with the Institutional Animal Care and Use Committee at Oregon Health and Science University, Portland, OR. Mice originally generated by the Bird laboratory (Guy et al., 2001), were obtained from the The Jackson Laboratory (strain no. 003890), maintained on a C57BL/6 background, and genotyped as described previously (Miralvès et al., 2007). Mice originally generated by the Jaenisch laboratory (Chen et al., 2001) were maintained on a BALB/c background and genotyped by PCR. Mice were group housed in standard plastic containers and were on a $12 \mathrm{~h}$ light/dark cycle. Food and water were available ad libitum. All experiments were performed on $M e c p 2 \mathrm{~B}^{-/ y}, M e c p 2 \mathrm{~J}^{-/ y}$, and Mecp2 $2^{+/-}$mice (Guy et al., 2001) and age-, sex-, and strain-matched wild-type (WT) controls. Females were divided into two age groups to separate presymptomatic and symptomatic $M e c p 2^{+/-}$mice: young $(16-30 \mathrm{~d})$ and adult $(169-519 \mathrm{~d})$. Mecp2B ${ }^{-/ y}$ males investigated were aged $30-57 \mathrm{~d}$ and Mecp2 $\mathrm{J}^{-1 y}$ males were 101105 d, ages where motor symptoms are observed (Chen et al., 2001; Guy et al., 2001). Motor symptoms in symptomatic animals, defined as hindlimb clasping, tremor, hypoactivity, and inertia, were confirmed before being killed. Littermates were used as age-matched controls when possible. When appropriate, experiments were performed with the investigator blind to the sex, age, and genotype.

Brain tissue and slice preparation. Mice were placed in a chamber, deeply anesthetized with isoflurane, and killed by decapitation. Brains were removed quickly and placed in an ice-cold, physiologically equivalent saline solution (modified Krebs' buffer) containing (in mM) 126 $\mathrm{NaCl}, 2.5 \mathrm{KCl}, 1.2 \mathrm{MgCl}_{2}, 2.4 \mathrm{CaCl}_{2}, 1.4 \mathrm{NaH}_{2} \mathrm{PO}_{4}, 25 \mathrm{NaHCO}_{3}$, and 11 D-glucose with $10 \mu \mathrm{M}$ MK-801. Striata were dissected, and thick (880 $\mu \mathrm{m})$ midbrain sections were frozen on dry ice and stored at $-80^{\circ} \mathrm{C}$ until use. Brain slices for electrophysiology and fast-scan cyclic voltammetry were prepared as described previously (Williams et al., 1984). Briefly, horizontal midbrain slices $(200-220 \mu \mathrm{m})$ or coronal slices containing dorsal striatum $(250 \mu \mathrm{m})$ were obtained using a vibrating microtome (Leica) and incubated at $34^{\circ} \mathrm{C}$ in vials with $95 / 5 \% \mathrm{O}_{2} / \mathrm{CO}_{2}$ saline and 10 $\mu \mathrm{M}$ MK-801 for at least $30 \mathrm{~min}$ to reduce excitotoxicity and increase slice viability.

Electrophysiology. Slices were mounted on a recording chamber attached to an upright microscope (Carl Zeiss), maintained at $34^{\circ} \mathrm{C}$, and perfused at a rate of $2.0 \mathrm{ml} / \mathrm{min}$ with modified Krebs' buffer. Using infrared illumination, dopamine cells of the $\mathrm{SN}$ were identified visually under $5 \times$ magnification by their location in relation to the midline and the medial terminal nucleus of the accessory optic tract. Physiological identification was based on the sensitivity to iontophoretically applied dopamine, a large hyperpolarization-induced $I_{\mathrm{h}}$ current, and the presence of spontaneous pacemaker firing of wide $(\sim 2 \mathrm{~ms})$ action potentials at $1-5 \mathrm{~Hz}$.

Whole-cell, patch-clamp recordings were obtained with glass electrodes (1.2-2.0 M $\Omega$; World Precision Instruments) and an internal solution containing (in mM): $115 \mathrm{~K}$-methylsulfate, $20 \mathrm{NaCl}, 1.5 \mathrm{MgCl}_{2}, 2$ ATP, 0.2 GTP, 10 phosphocreatine, and 10 BAPTA, pH 7.30-7.43, 275$288 \mathrm{mOsm}$. The cells were voltage clamped at $-60 \mathrm{mV}$ with an Axopatch 200B amplifier (Molecular Devices), below the threshold for spontaneous firing. Data were acquired using AxoGraph software (AxoGraphX) and Chart 5 (AD Instruments). Immediately after gaining access to the cell and before the application of any drug, membrane capacitance, series resistance, and input resistance were measured with the application of
20-50 pulses ( $\pm 2 \mathrm{mV}$ for $50 \mathrm{~ms}$ ) averaged before computation using AxoGraph (sampled at $50 \mathrm{kHz}$, filtered at $10 \mathrm{kHz}$ ). Series resistance was monitored to ensure sufficient and stable electrical access to the inside of the cell throughout the experiment $(<16 \mathrm{M} \Omega)$. Most experiments were conducted in the absence of synaptic receptor blockers in the external bath solution. The addition of the receptor blockers picrotoxin $(100 \mu \mathrm{M})$, hexamethonium $(50 \mu \mathrm{M})$, and DNQX $(10 \mu \mathrm{M})$ had no effect on the measurements made in this study. All drugs were applied through bath perfusion with the exception of dopamine, which was applied by iontophoresis. Iontophoretic pipettes were pulled from thin-walled glass microelectrodes (resistance 70-110 M $\Omega$ ) and filled with dopamine $(1 \mathrm{M})$, and the tip placed within $10 \mu \mathrm{m}$ of the soma. A negative backing current (3.0-8.0 nA) prevented passive leakage. Dopamine was ejected as a cation with the application of positive current (160 $\mathrm{nA}$ ) for 2-6s with an Axoclamp 2A amplifier (Molecular Devices) to elicit a maximal dopamine-induced outward current, verified with bath perfusion of quinpirole $(10 \mu \mathrm{M})$ for $2-3 \mathrm{~min}$, and reversed with sulpiride $(300 \mathrm{~nm})$.

Immunohistochemistry and morphology measurements. To determine whether recorded neurons expressed Mecp2, 0.1\% Neurobiotin was included in the internal solution (Vector Laboratories). Slices were fixed for $1 \mathrm{~h}$ in at room temperature in $4 \%$ paraformaldehyde in PBS. Freefloating slices were washed three times with PBS and then incubated in PBS with $0.5 \%$ Triton-X and $10 \%$ fetal bovine serum for $5 \mathrm{~h}$. Slices were incubated overnight at room temperature in rabbit anti-Mecp2 (Covance, 1:200). Slices were washed again in PBS and incubated in Alexa Fluor 488-conjugated goat anti-rabbit secondary antibody (1:1000, Invitrogen) for $2 \mathrm{~h}$. Slices were then washed three times with PBS and incubated in Cy5-conjugated streptavidin (1:1000, Invitrogen) for $2 \mathrm{~h}$. Following three PBS washes, slices were DAPI (300 nM) stained for $20 \mathrm{~min}$, rinsed, and mounted. Images were collected on a Zeiss confocal laser scanning LSM 710 microscope with a $20 \times$ lens $(0.8$ NA). Morphology measurements were calculated with the help of the Simple Neurite Tracer plug-in for Fiji.

Radioligand binding assays. The striata and midbrain from one mouse provided enough membranes for independent [ $\left.{ }^{3} \mathrm{H}\right] \mathrm{YM}-09151-2$ assays. The striata and midbrain section were homogenized with a PT $1200 \mathrm{E}$ Polytron (Kinematica) for $10 \mathrm{~s}$ on ice in $4 \mathrm{ml}$ of Tris buffer $(50 \mathrm{~mm}$ Tris- $\mathrm{HCl}, 0.9 \% \mathrm{NaCl}, \mathrm{pH} 7.4$, at $4^{\circ} \mathrm{C}$ ) and centrifuged at $30,000 \times \mathrm{g}$ for 20 min. The midbrain and striata membrane pellets were resuspended in 4 $\mathrm{ml}$ of Tris buffer, incubated for $30 \mathrm{~min}$ at $25^{\circ} \mathrm{C}$ to release endogenous dopamine, centrifuged, and resuspended in 2.6 and $6.0 \mathrm{ml}$ Tris buffer, respectively. Membranes (midbrain, 18-33 $\mu \mathrm{g}$; striata, 2-7 $\mu \mathrm{g}$ ) were incubated in duplicate in a total reaction volume of $1 \mathrm{ml}$ with $\left[{ }^{3} \mathrm{H}\right] \mathrm{YM}-$ 09151-2 (82.7 Ci/mmol; PerkinElmer) at concentrations ranging from 0.009 to $0.15 \mathrm{~nm}$ and buffer ( $50 \mathrm{~mm}$ Tris containing $0.9 \% \mathrm{NaCl}$ and $0.002 \%$ bovine serum albumin, $\mathrm{pH} 7.4$, at $4^{\circ} \mathrm{C}$ ). Nonspecific binding was measured in the presence of $1 \mu \mathrm{M}(+)$-butaclamol. Reactions were incubated at $25^{\circ} \mathrm{C}$ for $1 \mathrm{~h}$ and terminated by filtration through Wallac Filtermat A filters (PerkinElmer) presoaked with $0.05 \%$ polyethylenimine using a 96-well Tomtec cell harvester and ice-cold wash buffer $(10 \mathrm{~mm}$ Tris- $\mathrm{HCl}, \mathrm{pH} 7.4$, at $4^{\circ} \mathrm{C}$ and $0.9 \% \mathrm{NaCl}$ ). Filters were allowed to dry at least $1 \mathrm{~h}$ before adding scintillation fluid $(50 \mu \mathrm{l})$ to each filtered spot. Radioactivity on the filters was determined using a Wallac 1450 MicroBeta scintillation counter. Proteins were measured using the BCA method (Pierce Biotechnology).

Fast-scan cyclic voltammetry. Glass-encased carbon fibers (grade 34700, $7 \mu \mathrm{m}$ diameter; Goodfellow Corporation) were cut to a final exposed length of $\sim 30 \mu \mathrm{m}$ as described previously (Ford et al., 2010) and placed in the dorsal striatum. Voltammetric recordings were performed with a custom-built hardware (Electronics and Materials Engineering Shop, University of Washington, Seattle, WA) and software (Tarheel CV, LabView). To maximize the temporal resolution of the detection of dopamine, triangular waveforms from $-0.4 \mathrm{~V}$ to $1.0 \mathrm{~V}$ to $-0.4 \mathrm{~V}$ versus $\mathrm{Ag} / \mathrm{AgCl}$ with a scan rate of $600 \mathrm{~V} / \mathrm{s}$ at $60 \mathrm{~Hz}$ were used (Bath et al., 2000). Between scans the electrode was maintained at $-0.4 \mathrm{~V}$ (vs Ag/AgCl). Ten background cyclic voltammograms obtained before stimulation were used for subtraction. To determine the time course of voltammetrically detected dopamine, the current at the peak oxidation (0.5-0.7 V) was 
plotted against time. Dopamine was evoked by a single pulse $(0.35 \mu \mathrm{A}$, $0.5 \mathrm{~ms}$ ) from a monopolar stimulating electrode placed within the striatum near $(30-50 \mu \mathrm{m})$ the exposed tip of the carbon fiber. After the experiment, the electrode was calibrated using dopamine solutions of known concentration.

Drugs. Dopamine hydrochloride, MK-801, DNQX, picrotoxin, and (+)-butaclamol were obtained from Sigma-Aldrich. Hexamethonium, sulpiride, and baclofen were from Research Biochemicals International. CGP-35348 and quinpirole were obtained from Tocris Bioscience. $\left[{ }^{3} \mathrm{H}\right] \mathrm{YM}-09151-2(82.7 \mathrm{Ci} / \mathrm{mmol})$ was from PerkinElmer.

Data analysis. All values are given as means \pm SEM, with the exception of $K_{\mathrm{d}}$ values, which are given as geometric means followed by the limits defined by the SEM in parentheses. All distributions with $n>30$ were tested for normality with the Shapiro-Wilk normality test. Statistical significance were determined in two group comparisons by unpaired two-tailed $t$ tests or Mann-Whitney tests, and in more than two groups comparisons by one- or two-way ANOVAs or Kruskal-Wallis (nonparametric ANOVA) test and followed, when appropriate $(p<0.05)$, by Bonferroni's post hoc test or Dunn's multiple-comparisons test. Linear correlations in distributions were tested with Spearman correlation tests. Data for saturation binding were analyzed by nonlinear regression (Prism 4.0) using a one-site hyperbola model to determine $K_{d}$ and $B_{\max }$ values. The free concentration of radioligand was calculated as the concentration added minus the concentration specifically bound. A difference of $p<0.05$ was considered significant (InStat 3.06 and Prism 4.0; GraphPad Software).

\section{Results}

The effect of Mecp2 mutation on the electrophysiological properties of dopamine neurons was determined in presymptomatic and symptomatic female Mecp $2^{+/-}$mice. To unambiguously separate presymptomatic and symptomatic Mecp $2^{+/-}$mice, all young females [postnatal day (PND) $26 \pm 1, n=13$ ] used in these experiments were asymptomatic, whereas adult females (PND $347 \pm 19, n=23$ ) displayed motor symptoms, including hindlimb clasping and overt hypoactivity.

\section{Mecp2 - dopamine neurons have decreased capacitance and resting conductance}

To identify Mecp2 ${ }^{-}$and Mecp $2^{+}$neurons, cells were filled with $0.1 \%$ Neurobiotin and, after recording, were stained for the presence of Mecp2. In wild-type female mice, the Mecp2 antibody labeled $94 \%$ of filled neurons (WT). As illustrated in Figure $1 \mathrm{~A}$, dopamine neurons in heterozygous (HET) Mecp $2^{+/-}$mice were mosaic for Mecp2 expression with $\mathrm{Mecp}^{+}$(Fig. 1B) and Mecp2 $2^{-}$neurons (Fig. 1C), referred to as "HET " " and "HET ${ }^{-}$," respectively. In both $M e c p 2^{+/-}$and wild-type mice, there was a developmental decline in cell surface area as evidenced by a decrease in capacitance of $\mathrm{WT}, \mathrm{HET}^{+}$, and $\mathrm{HET}^{-}$dopamine neurons between young and adult ages (WT: $p<0.0001 ; \mathrm{HET}^{+}$: $p=0.0002$ HET $\left.^{-}: p<0.0001\right)$. The relative reduction in cell surface area that occurred between 1 and 8 months of age was similar between WT, $\mathrm{HET}^{+}$, and $\mathrm{HET}^{-}$neurons (two-way ANOVA, $\left.F_{(2,258)}=0.04, p=0.96\right)$. Despite this change, at both ages the capacitance of $\mathrm{HET}^{+}$neurons was indistinguishable from neurons in wild-type mice (Table $1 ; p>0.05$ ). On the contrary, $\mathrm{HET}^{-}$neurons were smaller than $\mathrm{HET}^{+}$and WT neurons. In all animals, the capacitance of $\mathrm{HET}^{-}$neurons was significantly less than that of age-matched $\mathrm{HET}^{+}$and WT neurons (Table 1; young: $p<0.05$; adult: $p<0.001$ ) (Fig. $1 D$ ).

Given limitations posed by the somatic recording electrode, capacitance measurements may not include more distal or fine processes. Therefore, morphology was examined by tracing neuron processes (axon and dendrites) in $x, y$, and $z$ dimensions to determine the number, length, and total length
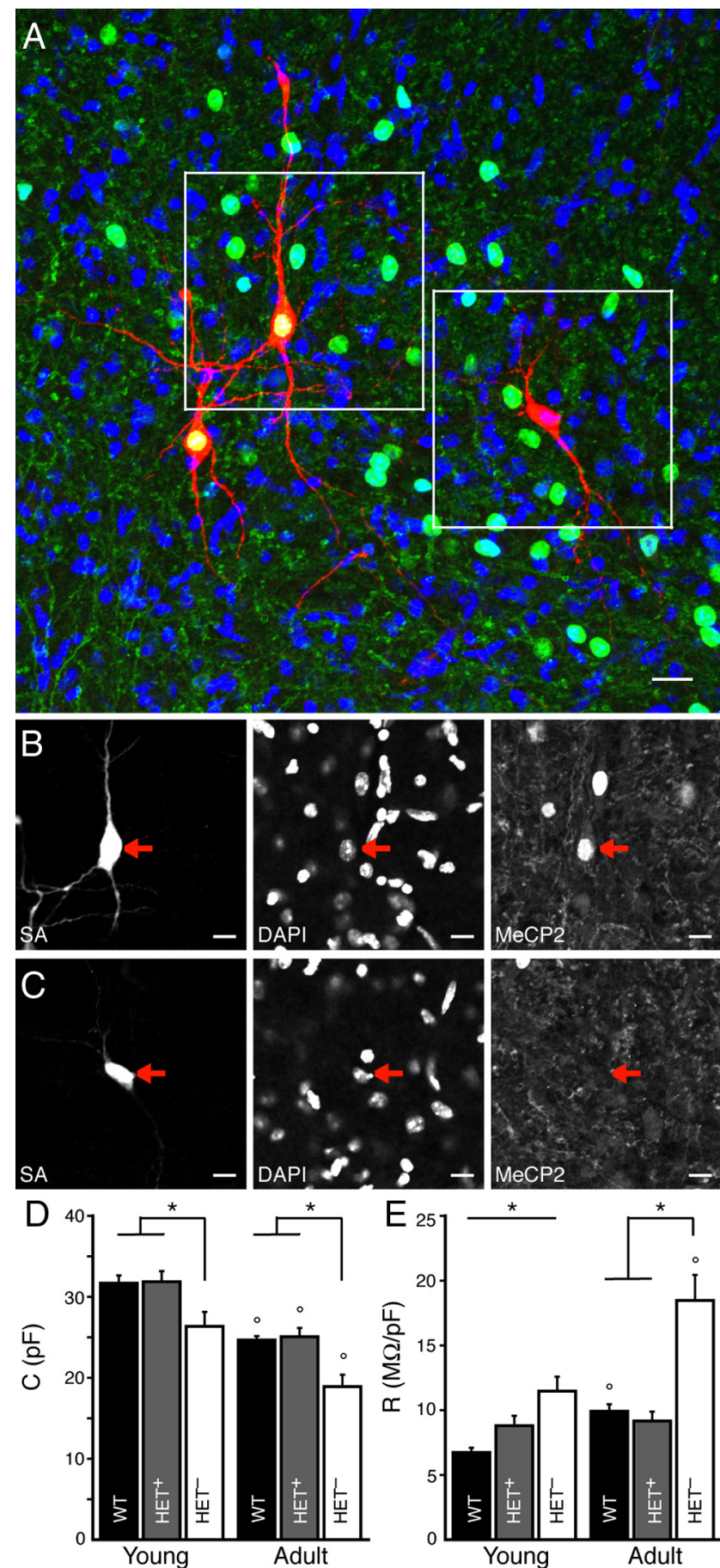

Figure 1. Mecp2 ${ }^{-}$dopamine neurons in Mecp $2^{+/-}$mice $\left(\mathrm{HET}^{-}\right)$have decreased membrane capacitance and increased resistance compared to Mecp2 ${ }^{+}$neurons from WT or Mecp $2^{+/-}\left(\mathrm{HET}^{+}\right)$female mice. $\boldsymbol{A}-\boldsymbol{C}$, Representative maximum intensity projection confocal images of neurobiotin-filled $\mathrm{HET}^{+}$and $\mathrm{HET}^{-}$dopamine neurons from the SN of a young Mecp $2^{+/-}$female immunostained with streptavidin (SA, red), antibody for Mecp2 (green), and DAPI (blue) $(\boldsymbol{A})$. Single plane confocal image of $\mathrm{HET}^{+}(\boldsymbol{B})$ and HET $^{-}$nuclei (C). Scale bars: (in $\boldsymbol{A}$ ), $20 \mu \mathrm{m}$; (in $\boldsymbol{B}, \boldsymbol{C}$ ), $10 \mu \mathrm{m}$. $\boldsymbol{D}$, The capacitance (pF) of dopamine neurons decreased with age in wild-type and $M e c p 2^{+/-}$mice, indicating a significant decrease in the surface area of dopamine neurons with age in both wild-type and $M e c p 2^{+/-}$mice. Capacitance of HET dopamine neurons was significantly less than WT and HET ${ }^{+}$in young and adult mice. $\boldsymbol{E}$, Resistance $(\mathrm{M} \Omega / \mathrm{pF})$ of dopamine neurons in wild-type and $M e c p 2^{+/-}$mice increased with age. Resistance of $\mathrm{HET}^{-}$neurons was greater than WT in young and adult mice. Mean \pm SEM; asterisk $\left({ }^{*}\right)$ designates statistical significance within age group, circle $\left({ }^{\circ}\right)$ designates statistical significance compared to young age. 
Table 1. Characteristics of dopamine neurons in wild type and $M e c p 2^{+/-}$females

\begin{tabular}{|c|c|c|c|c|c|c|}
\hline \multirow{3}{*}{$\begin{array}{l}\text { Age } \\
\text { Mecp2 }\end{array}$} & \multicolumn{2}{|l|}{ Mecp $2^{+/+}$} & \multicolumn{4}{|l|}{ Mecp2 $2^{+/-}$} \\
\hline & \multirow{2}{*}{$\frac{\text { Young }(26-30 \mathrm{~d})}{+}$} & \multirow{2}{*}{$\frac{\text { Adult }(250-812 d)}{+}$} & \multicolumn{2}{|l|}{ Young $(27-30 \mathrm{~d})$} & \multicolumn{2}{|l|}{ Adult $(270-519 d)$} \\
\hline & & & + & - & + & - \\
\hline Capacitance (pF) & $31.7 \pm 1.0(41)$ & $24.7 \pm 0.5^{\circ}(127)$ & $31.9 \pm 1.3(26)$ & $26.4 \pm 1.8^{* \ddagger}(20)$ & $25.1 \pm 1.1^{\circ}(32)$ & $18.9 \pm 1.5^{\text {*॰o }}(18)$ \\
\hline Resistance $(\mathrm{M} \Omega / \mathrm{pF})$ & $6.7 \pm 0.3(41)$ & $9.9 \pm 0.5^{\circ}(82)$ & $8.8 \pm 0.8(26)$ & $11.5 \pm 1.1^{*}(20)$ & $9.2 \pm 0.7(32)$ & $18.5 \pm 2.0^{* \neq \circ}(18)$ \\
\hline Number of processes & $13.3 \pm 0.5(25)$ & $10.4 \pm 0.5^{\circ}(25)$ & $13.0 \pm 0.6(23)$ & $10.2 \pm 0.6^{* \ddagger}(19)$ & $10.4 \pm 0.4^{\circ}(30)$ & $9.6 \pm 0.5(16)$ \\
\hline Length of processes ( $\mu \mathrm{m})$ & $110.5 \pm 6.0(25)$ & $108.7 \pm 4.8(25)$ & $103.8 \pm 6.2(23)$ & $101.3 \pm 5.3(19)$ & $104.0 \pm 5.5(30)$ & $81.9 \pm 5.8^{* \neq \circ}(16)$ \\
\hline Total length of processes $(\mu \mathrm{m})$ & $1453 \pm 83(25)$ & $1132 \pm 84^{\circ}(25)$ & $1353 \pm 99(23)$ & $1012 \pm 64^{* \ddagger}(19)$ & $1074 \pm 61^{\circ}(30)$ & $792 \pm 78^{\text {*。 }}(16)$ \\
\hline Dopamine current density (pA/pF) & $8.1 \pm 0.4(39)$ & $7.7 \pm 0.3(111)$ & $7.8 \pm 0.4(26)$ & $7.0 \pm 0.5(19)$ & $7.0 \pm 0.5(29)$ & $5.0 \pm 0.7^{* \neq \circ}(17)$ \\
\hline
\end{tabular}

Boldface designates statistical significance. The number of cells is shown in parentheses.

*Statistical significance compared to age-matched wild type.

*Statistical significance compared to age-matched HET ${ }^{+}$

`Statistical significance compared to young age within genotype.

of processes. Representative maximum intensity projection images of neurons and their tracings are shown in Figure $2 A$. In both $M e c p 2^{+/-}$and wild-type mice, the number of processes decreased between young and adult ages (Fig. 2B). Despite this developmental change, in all animals the morphology of age-matched $\mathrm{HET}^{+}$or WT neurons was indistinguishable (Table $1 ; p>0.05$ ) (Fig. $2 B-D$ ). However, $\mathrm{HET}^{-}$neurons from young females had fewer dendrites (Table 1, $p<0.01)$ but no significant difference in the average dendrite length (Table 1, $p>0.05$ ) (Fig. $2 B, D$ ). In adulthood, the total length of the dendritic arbor of $\mathrm{HET}^{-}$neurons remained smaller (Table $1 ; p<0.05)$ and the average dendrite length was reduced (Table $1 ; p<0.05$ ) (Fig. 2C,D).

Overall, these results indicate the expression of Mecp2 in $\mathrm{HET}^{+}$neurons is sufficient to develop and maintain WT morphology. However, loss of Mecp2 in $\mathrm{HET}^{-}$dopamine neurons results in less membrane surface area, due in part to fewer dendrites, months before the onset of any motor deficit. In symptomatic mice, $\mathrm{HET}^{-}$neurons continue to have significantly less membrane surface area and a smaller dendritic arbor than Mecp $2^{+}$ neurons.

As might be expected from the decrease in capacitance with age, the input resistance also increased in neurons from wild-type and $M e c p 2^{+/-}$animals. The increase in resistance in $\mathrm{WT}_{\text {and }} \mathrm{HET}^{-}$neurons was not, however, in proportion to the decrease in capacitance, indicating that after PND 30 there was a developmental decrease in the expression of ion channels that contribute to the resting conductance (WT: $p=0.0002 \mathrm{HET}^{-}$: $p=0.0036$ ) (Fig. $1 E$ ). In both young and adult animals, the resistance of $\mathrm{HET}^{+}$and WT neurons was indistinguishable (Table $1 ; p>0.05$ ) (Fig. $1 E$ ). However, $\mathrm{HET}^{-}$neurons had an increased resistance at both ages (Table 1; young: $p<0.001$; adult: $p<0.001$ ) (Fig. $1 E$ ). Overall, these results indicate that a specific consequence of Mecp2 loss is a reduction in the density of open ion channels underlying the resting conductance. pared to young age.
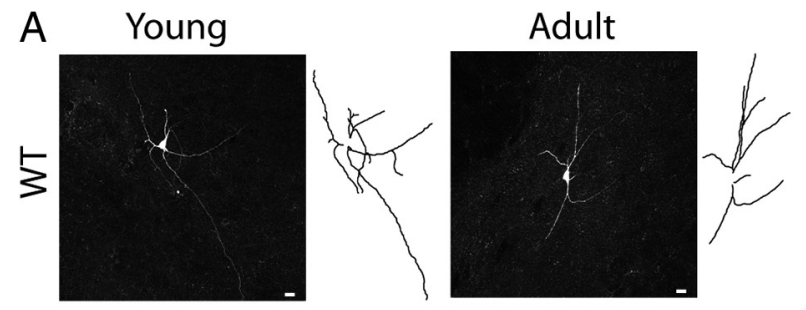

B
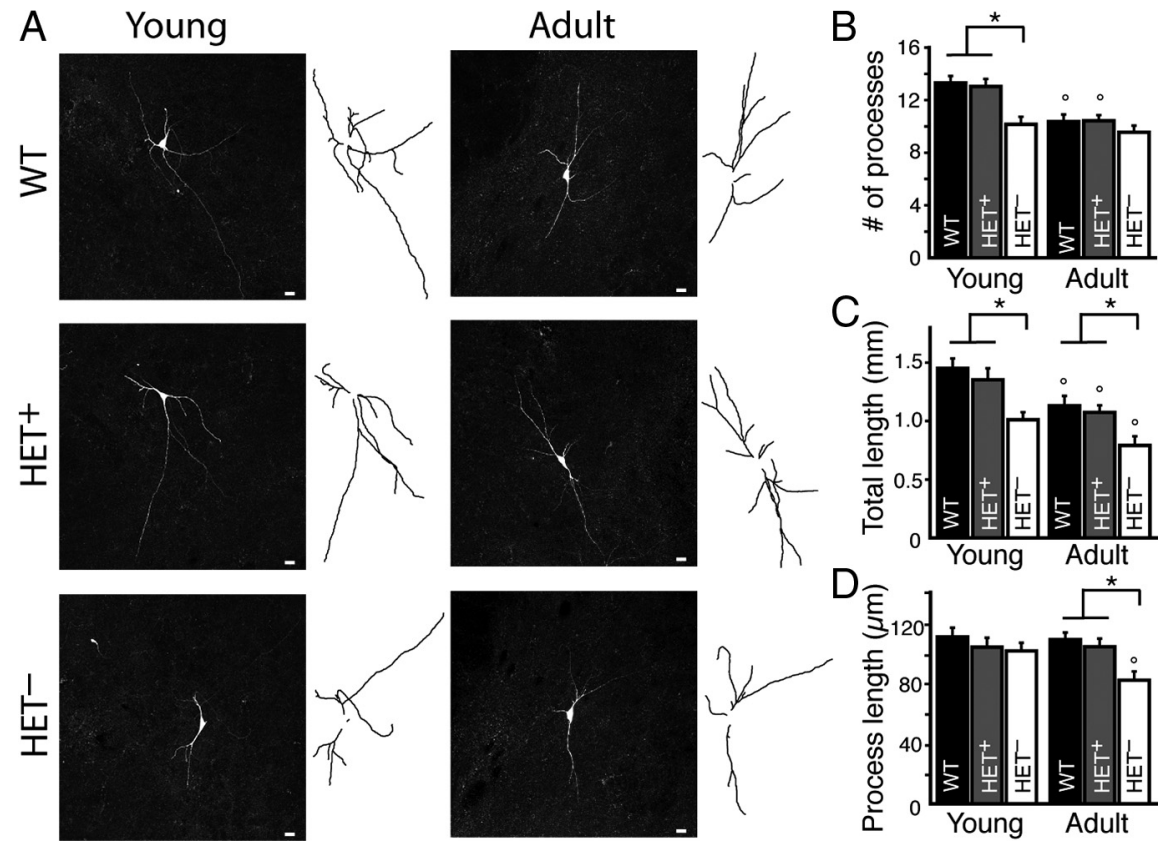

Figure 2. Mecp2 ${ }^{-}$dopamine neurons in $M e c p 2^{+/-}$mice $\left(\mathrm{HET}^{-}\right)$have a reduced dendritic arbor compared to Mecp2 ${ }^{+}$ neurons from WT or Mecp $2^{+/-}\left(\mathrm{HET}^{+}\right)$female mice. $\boldsymbol{A}$, Representative maximum intensity projection confocal images and tracings of neurobiotin-filled WT, $\mathrm{HET}^{+}$, and HET ${ }^{-}$dopamine neurons from the SN of young and adult wild-type and Mecp $2^{+/-}$ mice. $\boldsymbol{B}$, The number of processes (dendrites and axon) on dopamine neurons decreased with age in wild-type and $M e c p 2^{+/-}$ mice, indicating a developmental pruning of dendrites. $\mathrm{HET}^{-}$neurons had fewer dendrites than WT and HET ${ }^{+}$neurons in young animals. There was no difference in the number of dendrites on WT and HET ${ }^{+}$neurons. C, The total length of processes (in $\mathrm{mm}$ ) decreased with age in wild-type and $M e c p 2^{+/-}$mice. The total length of processes in HET ${ }^{-}$neurons was significantly less than those in WT or HET ${ }^{+}$neurons in both young and adult animals. There was no difference in the total length of processes in WT and $\mathrm{HET}^{+}$neurons. $\boldsymbol{D}$, The average process length (in $\mu \mathrm{m}$ ) of WT and HET ${ }^{+}$neurons was not different and did not change with age. Processes from $\mathrm{HET}^{-}$neurons from adult Mecp ${ }^{+/-}$mice were significantly shorter than age-matched WT and HET ${ }^{+}$neurons. Mean $\pm \mathrm{SEM}$; asterisk $\left(^{*}\right)$ designates statistical significance within age group; circle $\left({ }^{\circ}\right)$ designates statistical significance com-

\section{$D_{2}$ autoreceptor-activated current density is attenuated in} symptomatic Mecp $2^{+/-}$mice from a specific decrease in Mecp2 ${ }^{-}$neurons

A fundamental property of $\mathrm{SN}$ dopamine neurons is the presence of $\mathrm{D}_{2}$ autoreceptors, which activate a potassium conductance. Therefore, binding of $\mathrm{D}_{2}$ receptors and their activation, measured as the current induced by dopamine in neurons from $M e c p 2^{+/-}$mice, was examined. Initially, maximal $\mathrm{D}_{2}$ receptoractivated outward currents were evoked by iontophoretic application of dopamine onto dopamine neurons in female wild-type mice (Fig. 3A). The maximal dopamine current evoked by iontophoresis did not differ in amplitude from bath perfusion of the $\mathrm{D}_{2}$ 


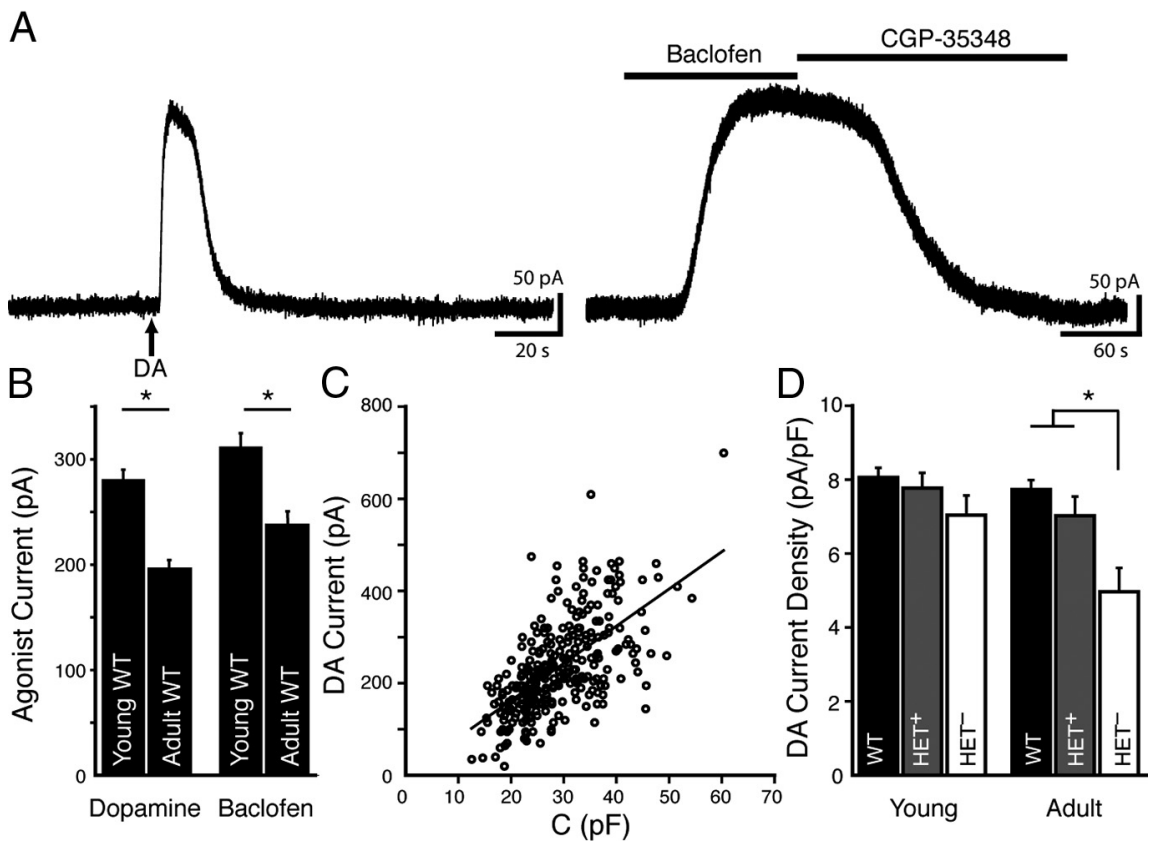

Figure 3. Dopamine current density (pA/pF) was significantly reduced in $\mathrm{HET}^{-}$neurons from the substantia nigra of symptomatic adult $\mathrm{Mecp}^{+/-}$mice. $A$, Representative trace of outward currents in wild-type female mice induced by iontophoretic action of dopamine (arrow, $160 \mathrm{nA}, 2 \mathrm{~s}$ ) and bath application of baclofen $(10 \mu \mathrm{M}$ ), which reversed with bath application of the $\mathrm{GABA}_{\mathrm{B}}$ antagonist (GP-35348 (30 $\left.\mu \mathrm{M}\right)$. B, Raw current amplitudes (pA) showing a significant decrease in dopamine-and baclofeninduced currents in adult wild-type mice. $C$, Linear correlation between capacitance $(\mathrm{pF})$ and amplitude of dopamine-evoked outward current in wild-type females (pA) $\left(R_{294}=0.64, p<0.0001\right)$, indicating that amplitude of dopamine-evoked outward current is directly proportional to membrane surface area. $\boldsymbol{D}$, The dopamine current density $(\mathrm{pA} / \mathrm{pF})$ of WT and $\mathrm{HET}^{+}$neurons was not different in young or adult mice. The dopamine current density of HET ${ }^{-}$neurons was significantly less than WT and $\mathrm{HET}^{+}$ neurons in adult animals. Mean \pm SEM; asterisk $\left(^{*}\right)$ designates statistical significance.

agonist quinpirole ( $10 \mu \mathrm{M}$; quinpirole: $248 \pm 16 \mathrm{pA}, n=29$; DA: $234 \pm 6 \mathrm{pA}, n=296 ; p>0.05$; Beckstead et al., 2009). The amplitude of the maximal dopamine current decreased with age, which may not be surprising given the reduction in membrane surface area (young: $280 \pm 11 \mathrm{pA}, n=95$; adult: $196 \pm 9 \mathrm{pA}, n=$ $111 ; p<0.0001$ ) (Fig. 3B). When normalized to capacitance, the dopamine current density did not change with age in wild-type mice (Table $1 ; p>0.05$ ) (Figs. 3D, $4 A$ ).

The activation of $\mathrm{GABA}_{\mathrm{B}}$ receptors on $\mathrm{SN}$ dopamine neurons activates the same $\mathrm{G}$ protein-coupled inwardly rectifying potassium (GIRK) conductance as $\mathrm{D}_{2}$ receptors (Beckstead et al., 2004; Koyrakh et al., 2005). Consistent with a previous report that $\mathrm{GABA}_{\mathrm{B}}$ receptors activate the GIRK conductance with greater efficacy (Beckstead et al., 2009), the maximal current induced by the $\mathrm{GABA}_{\mathrm{B}}$ agonist baclofen $(10 \mu \mathrm{M})$ was significantly greater than the maximal dopamine current in neurons from adult wildtype mice $(p<0.05)$. Similar to dopamine, the maximal baclofen-induced current decreased with age (young: $311 \pm 14$ pA, $n=61$; adult: $237 \pm 13$ pA, $n=40 ; p=0.01$ ) (Fig. $3 B$ ), but when normalized to cell capacitance there was no change in the baclofen current density with age (young: $8.7 \pm 0.4 \mathrm{pA} / \mathrm{pF}, n=$ 61; adult: $9.1 \pm 0.4 \mathrm{pA} / \mathrm{pF}, n=40 ; p>0.05$ ) (Fig. $4 A$ ). Thus, in wild-type animals the correlation between capacitance and agonist-induced GIRK current amplitude indicated that cell size predicts the amplitude of the current induced by activation of these two $G$ protein-coupled receptors (Spearman correlation; DA: $R_{294}=0.64, p<0.0001$, Fig. $3 C$; baclofen: $R_{169}=0.46, p<$ 0.0001 ; data not shown).

To evaluate the effect of Mecp2 mutation on the sensitivity to exogenously applied dopamine, the dopamine current density in presymptomatic (young), symptomatic (adult) $M e c p 2^{+/-}$, and age-matched wild-type mice was compared. In young females, the dopamine current density of the combined population of Mecp $2^{+}$and Mecp $2^{-}$neurons in Mecp $2^{+/-}$mice, referred to as "HET ${ }^{+/-"}(7.5 \pm 0.2 \mathrm{pA} / \mathrm{pF}$, $n=100)$, and wild-type mice was not different $(p>0.05)$ (Fig. $4 A)$. Nor was there a difference in young females between the dopamine current densities in WT, $\mathrm{HET}^{+}$, or $\mathrm{HET}^{-}$neurons $(p>0.05)$ (Fig. $3 D)$. However, in adult Mecp $2^{+/-}$mice, the average dopamine current density of the $\mathrm{HET}^{+/-}$neuron population $(6.5 \pm$ $0.2 \mathrm{pA} / \mathrm{pF}, n=150$ ) was reduced significantly compared to the wild-type controls $(p=0.0001)$ (Fig. 4A). The decrease in dopamine current density was due to a cell-autonomous decrease in $\mathrm{HET}^{-}$neurons (Table $1 ; p<0.05$ ) (Fig. 3D). In both young and adult mice, $\mathrm{HET}^{+}$neurons were indistinguishable from WT neurons (Table $1 ; p>0.05$ ) (Fig. 3D). The decrease in dopamine current was selective because the average $\mathrm{GABA}_{\mathrm{B}}$ receptor-mediated current density of $\mathrm{HET}^{+/-}$neurons was unaltered at both ages in $M e c p 2^{+/-}$mice (young: $8.4 \pm 0.3 \mathrm{pA} / \mathrm{pF}, n=39 ; p>0.05$; adult: $8.5 \pm 0.4 \mathrm{pA} / \mathrm{pF}, n=38 ; p>0.05)$ (Fig. $4 A$ ). The attenuated dopamine current density was observed in the presence and absence of $\mathrm{GABA}_{\mathrm{A}}$, AMPA, and nicotinic ACh synaptic blockers. There was no standing outward current, indicating a lack of significant constitutive $\mathrm{D}_{2}$ autoreceptor activation in the brain slice. Overall, these results suggest that the loss of Mecp2 reduces the sensitivity of dopamine neurons to dopamine by adulthood.

The decrease in sensitivity of dopamine neurons to dopamine could be due to an alteration in the number of $\mathrm{D}_{2}$ autoreceptors in the nigrostriatal pathway. Therefore, saturation binding experiments were performed on midbrain and striatum homogenates from young and adult wild-type and $M e c p 2^{+/-}$mice by using a highly selective and potent $\mathrm{D}_{2}$ receptor antagonist, $\left[{ }^{3} \mathrm{H}\right] \mathrm{YM}$ 09151-2 (Terai et al., 1989). Mean $K_{\mathrm{d}}$ values in these regions were $\sim 20 \mathrm{pm}$ (Table 2), consistent with previously reported values (Terai et al., 1989). In both Mecp $2^{+/-}$and wild-type mice there was no significant age-related change in the density of $\mathrm{D}_{2}$ receptors in midbrain, as evidenced by comparable $B_{\max }$ values of $\left[{ }^{3} \mathrm{H}\right] \mathrm{YM}-09151-2$ binding between young and adult ages $(p>$ 0.05 ; Table 2). However, there was a developmental decline in the density of $\mathrm{D}_{2}$ receptors in striatum in both $M e c p 2^{+/-}$and wildtype mice (wild type: $p<0.05$; Mecp $2^{+/-}: p<0.05$; Table 2). The relative reduction in $\mathrm{D}_{2}$ receptors was similar between wild-type and $M e c p 2^{+/-}$mice (two-way ANOVA; midbrain, $F_{(1,19)}=0.02$, $p=0.90$; striatum, $\left.F_{(1,16)}=0.007, p=0.94\right)$. Furthermore, at both ages, the density of $\mathrm{D}_{2}$ receptors in midbrain and striatum from $M e c p 2^{+/-}$mice was indistinguishable from the density of $\mathrm{D}_{2}$ receptors in wild-type mice ( $p>0.05$; Table 2$)$. Thus, loss of Mecp2 in SN dopamine neurons results in a cell autonomous reduction in membrane surface area and resting conductance, as well as a progressive decline in dopamine $\mathrm{D}_{2}$ autoreceptor signal- 


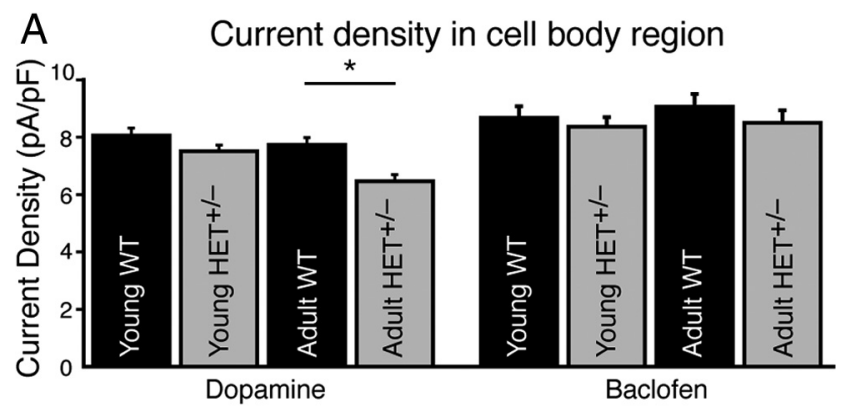

B Dopamine release in terminal region

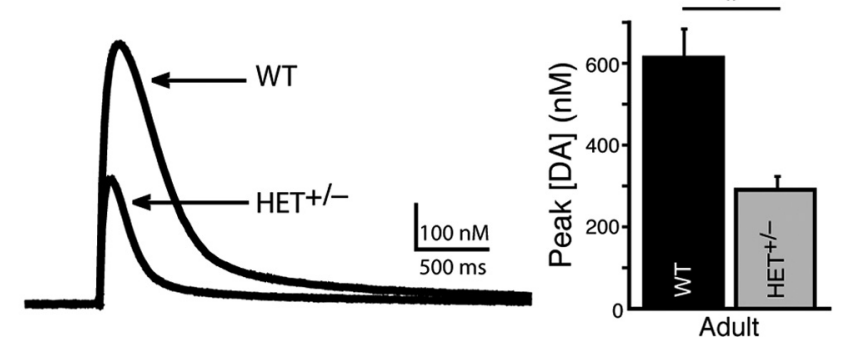

Figure 4. Adult Mecp2 $2^{+/-}$mice have decreased dopamine current density in the SN and attenuated release of dopamine from axon terminals. $\boldsymbol{A}$, Dopamine and baclofen current densities ( $\mathrm{pA} / \mathrm{pF}$ ) did not change with age in wild-type females. The dopamine current density of the combined population of Mecp2 ${ }^{+}$and Mecp2 ${ }^{-}$dopamine neurons (HET ${ }^{+/-}$) was significantly smaller in adult Mecp $2^{+/-}$females compared to wild-type. $B, A$ single stimulation was used to evoke dopamine release from axon terminals in the dorsal striatum of adult WT and Mecp $2^{+/-}\left(\mathrm{HET}^{+/-}\right)$mice. In adult Mecp $2^{+/-}$mice, less than half the amount of dopamine was released than in wild-type mice (left). Summarized data illustrating the peak concentration (in $\mathrm{nm}$ ) of the dopamine transient (right). Mean \pm SEM; asterisk $\left(^{*}\right)$ designates statistical significance.

ing, without altering the density of $\mathrm{D}_{2}$ receptors in midbrain or striatum.

\section{Similar cellular defects in symptomatic Mecp $2^{-/ y}$ mice}

Similar Parkinson-like motor deficits occur in Mecp $2^{-/ y}$ males as in Mecp $2^{+/-}$female mice. Mecp $2^{+/-}$female mice used in this study were originally generated by the Bird laboratory and maintained on a C57BL/6 background. To determine gender- or strain-specific effects, two different mouse models of RTT were used. The electrophysiological properties of dopamine neurons were determined in symptomatic males Mecp $2^{-1 y}$ mice generated by the Bird and Jaenisch laboratories [Bird (B): Mecp2B ${ }^{-/ y}$, MUT $^{\mathrm{B}}$, PND $44 \pm 4, n=14$; Jaenisch (J): Mecp2J ${ }^{-/ y}, \mathrm{MUT}^{\mathrm{J}}$, PND $103 \pm 1, n=4]$. Reduced capacitance was observed in Mecp2 $^{-}$SN dopamine neurons in Mecp2B ${ }^{-/ y}$ and Mecp2 ${ }^{-/ y}$ male mice $\left(\mathrm{WT}^{\mathrm{B}}: 30.1 \pm 0.9 \mathrm{pF}, n=70 ; \mathrm{MUT}^{\mathrm{B}}: 20.0 \pm 0.7 \mathrm{pF}\right.$, $n=48 ; p<0.0001 ; \mathrm{WT}^{\mathrm{J}}: 25.7 \pm 1.0 \mathrm{pF}, n=28 ; \mathrm{MUT}^{\mathrm{J}}: 18.0 \pm 0.7$ $\mathrm{pF}, n=31$; $p<0.0001$ ) (Fig. $5 A$ ). Additionally, increased resistance was observed in Mecp2 ${ }^{-}$neurons from Mecp2B ${ }^{-/ y}$ and Mecp2J ${ }^{-1 y}$ male mice $\left(\mathrm{WT}^{\mathrm{B}}: 9.5 \pm 0.5 \mathrm{M} \Omega / \mathrm{pF}, n=56 ; \mathrm{MUT}^{\mathrm{B}}\right.$ : $20.6 \pm 2.4 \mathrm{M} \Omega / \mathrm{pF}, n=33 ; p<0.0001 ; \mathrm{WT}^{\mathrm{J}}: 14.3 \pm 1.1 \mathrm{M} \Omega / \mathrm{pF}$, $n=28$; $\mathrm{MUT}^{\mathrm{J}}: 32.1 \pm 3.3 \mathrm{M} \Omega / \mathrm{pF}, n=31 ; p<0.0001$; data not shown). Finally, as was observed in experiments in adult $M e c p 2^{+/-}$females, the dopamine current density in the symptomatic Mecp2B ${ }^{-/ y}$ and Mecp2 $\mathrm{J}^{-/ y}$ mice was significantly decreased $\left(\mathrm{WT}^{\mathrm{B}}\right.$ : $10.0 \pm 0.4 \mathrm{pA} / \mathrm{pF}, n=49 ; \mathrm{MUT}^{\mathrm{B}}: 7.6 \pm 0.4$ $\mathrm{pA} / \mathrm{pF}, n=32 ; p=0.0002 ; \mathrm{WT}^{\mathrm{J}}: 9.7 \pm 0.6 \mathrm{pA} / \mathrm{pF}, n=25 ; \mathrm{MUT}^{\mathrm{J}}$ : $5.5 \pm 0.5 \mathrm{pA} / \mathrm{pF}, n=28 ; p=0.002$ ) (Fig. $5 B$ ), while baclofen current density did not change significantly $\left(\mathrm{WT}^{\mathrm{B}}: 8.9 \pm 0.4\right.$ $\mathrm{pA} / \mathrm{pF}, n=48 ; \mathrm{MUT}^{\mathrm{B}}: 7.6 \pm 0.6 \mathrm{pA} / \mathrm{pF}, n=15 ; p=0.07 ; \mathrm{WT}^{\mathrm{J}}$ : $9.8 \pm 0.6 \mathrm{pA} / \mathrm{pF}, n=21 ; \mathrm{MUT}^{\mathrm{J}}: 8.5 \pm 0.8 \mathrm{pA} / \mathrm{pF}, n=17, p>$
0.05; data not shown). Therefore, the cellular defects observed in Mecp2 ${ }^{-}$neurons from symptomatic Mecp $2^{+/-}$females were recapitulated in Mecp2 $2^{-}$neurons from symptomatic Mecp2 $2^{-/ y}$ male mice.

The cellular defects observed in Mecp $2^{-}$neurons from young Mecp $2^{+/-}\left(\mathrm{PND} 26-30, \mathrm{HET}^{-}\right.$) and Mecp2B ${ }^{-/ y}$ (PND 30-45, $\mathrm{MUT}^{\mathrm{B}}$ ) mice were compared by two-way ANOVA, where a significant interaction between sex and proteotype indicates a difference in the severity of defects. When the capacitance of young $\operatorname{MUT}^{\mathrm{B}}(66 \pm 2 \%$ of WT $)$ and $\mathrm{HET}^{-}(83 \pm 6 \%$ of WT $)$ neurons were compared, there was a significant interaction between sex and proteotype (two-way ANOVA, $F_{(1,108)}=5.9, p=0.02$ ). This result indicates an additional reduction in surface area in young MUT $^{\mathrm{B}}$ neurons that was not detected in young $\mathrm{HET}^{-}$neurons. When the resistance of young MUT $^{\mathrm{B}}(176 \pm 19 \%$ of WT) and $\mathrm{HET}^{-}(170 \pm 16 \%$ of WT $)$ neurons were compared, there was no interaction between sex and proteotype (two-way ANOVA, $\left.F_{(1,100)}=1.9, p=0.18\right)$. There was also no interaction when the dopamine current density of young $\mathrm{MUT}^{\mathrm{B}}(73 \pm 4 \%$ of WT) and $\mathrm{HET}^{-}(86 \pm 7 \%$ of WT) neurons were compared (two-way ANOVA, $\left.F_{(1,89)}=2.3, p=0.13\right)$. These results indicate that the decrease in resting conductance and dopamine current density relative to wild type was similar in $\mathrm{MUT}^{\mathrm{B}}$ and $\mathrm{HET}^{-}$neurons in young mice. In symptomatic adult Mecp $2^{+/-}$mice, the specific attenuation in dopamine current density in $\mathrm{HET}^{-}$neurons, reduces the average dopamine current density of the SN to a level comparable to that of symptomatic Mecp2 $\mathrm{B}^{-/ y}$ mice $\left(\mathrm{HET}^{+/-}\right.$: $84 \pm 3 \%$ of WT; MUT ${ }^{\mathrm{B}}: 76 \pm 4 \%$ of WT; two-way ANOVA, $\left.F_{(1,338)}=2.7, p=0.10\right)$.

\section{Less dopamine is released in the striatum of symptomatic} Mecp $2^{+/-}$mice

The release of dopamine in the dorsal striatum of adult Mecp $2^{+/-}$ mice was measured by fast-scan cyclic voltammetry to examine the possibility that morphological and functional defects observed in Mecp2 ${ }^{-}$SN dopamine neurons affect terminal release. A single stimulus evoked dopamine release from SN dopamine neuron axonal terminals in the dorsal striatum (Fig. $4 B$ ). The amount of dopamine released in adult $M e c p 2^{+/-}$mice $(291 \pm 32$ $\mathrm{nM}, n=41)$ was less than half the amount released in adult female wild-type mice ( $614 \pm 74 \mathrm{nM}, n=35 ; p=0.0002$ ) (Fig. $4 B$ ). These results suggest that when stimulated, less dopamine is released in the terminal projection area of dorsal striatum in adult mice as a consequence of heterogeneous loss of Mecp2 in SN dopamine neurons.

\section{Discussion}

The present study suggests that the mosaic expression of Mecp2 in the $\mathrm{SN}$ results in a compromised nigrostriatal pathway, in part due to morphological and functional alterations specific to Mecp2 ${ }^{-}$neurons. Examination of dopamine neurons in aging animals addressed three issues related to the cellular basis of Rettlike symptoms in mice: (1) the timing of defects with respect to the presentation of behavioral symptoms; (2) the consequence of Mecp2 loss on SN dopamine neuron morphology and function; and (3) the consequence of heterogeneous Mecp2 expression on the function of the nigrostriatal pathway.

\section{Age-dependent changes in wild-type dopamine neurons}

Numerous rodent and human studies have addressed the consequence of age on the number of $\mathrm{D}_{2}$ receptors in the nigrostriatal pathway. Previous reports describe a reduction in $\mathrm{D}_{2}$ receptor density in the striatum with age (Severson and Finch, 1980; De 
Table 2. Binding densities and affinities of $\left[{ }^{3} \mathrm{H}\right] \mathrm{YM}-09151-2$ in midbrain and striatum do not differ between age-matched wild-type and $M$ ecp2 ${ }^{+/-}$females

\begin{tabular}{|c|c|c|c|c|c|c|c|}
\hline \multirow[b]{2}{*}{ Region } & \multirow[b]{2}{*}{ Age } & \multicolumn{2}{|l|}{$K_{\mathrm{d}}(\mathrm{pm})$} & \multicolumn{2}{|c|}{$B_{\max }(\mathrm{fmol} / \mathrm{mg}$ protein $)$} & \multicolumn{2}{|l|}{$n$} \\
\hline & & Mecp2 $2^{+/+}$ & Mecp2 ${ }^{+/-}$ & $\operatorname{Mecp2}^{+/+}$ & Mecp2 $2^{+/-}$ & $\operatorname{Mecp2}^{+/+}$ & $\operatorname{Mecp2^{+/-}}$ \\
\hline \multirow[t]{2}{*}{ Midbrain } & Young $(26-37 d)$ & $18(16-20)$ & $29(19-44)$ & $58.2 \pm 6.9$ & $58.8 \pm 10.0$ & 7 & 3 \\
\hline & Adult (169-446 d) & $24(23-26)$ & $23(19-27)$ & $44.7 \pm 2.0$ & $43.8 \pm 4.6$ & 7 & 6 \\
\hline \multirow[t]{2}{*}{ Striatum } & Young (26-37d) & $16(13-19)$ & $18(13-25)$ & $709.7 \pm 48.9$ & $737.9 \pm 12.8$ & 4 & 3 \\
\hline & Adult $(169-446 \mathrm{~d})$ & $17(15-19)$ & $17(15-20)$ & $569.6 \pm 17.9^{\circ}$ & $591.6 \pm 45.2^{\circ}$ & 7 & 6 \\
\hline
\end{tabular}

The affinity $\left(K_{\mathrm{d}}\right)$ and density $\left(B_{\max }\right)$ of $\mathrm{D}_{2}$ receptors were determined by saturation analysis of binding of $\left[{ }^{3} \mathrm{H}\right] \mathrm{YM}-09151-2$ in membranes prepared from three to seven brains as described under Materials and Methods. $K_{\mathrm{d}}$ values are the geometric means, followed by the limits defined by the SEM in parentheses. $B_{\max }$ values represent the mean \pm SEM; the symbol ${ }^{\circ}$ designates statistical significance compared to young age within genotype. Boldface designates statistical significance.
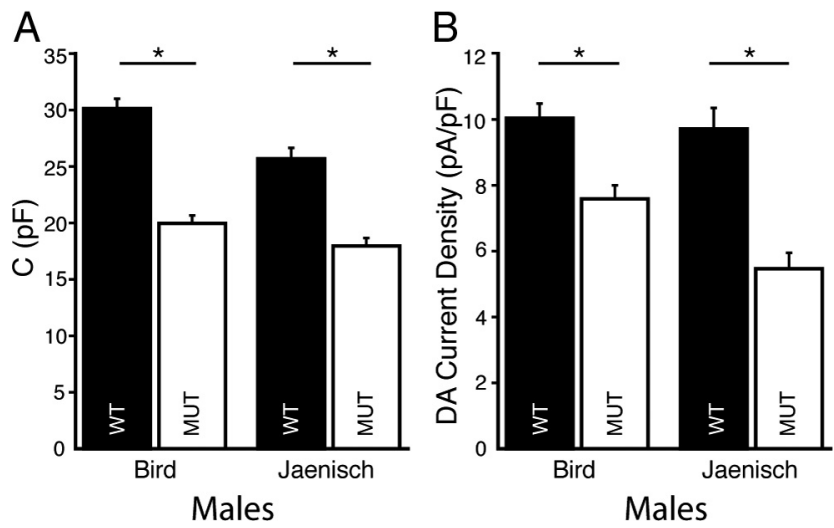

Figure 5. Mecp2 ${ }^{-}$dopamine neurons from symptomatic Mecp2B ${ }^{-1 y}$ (Bird, PND $30-57$ ) and Mecp2J ${ }^{-1 y}$ (Jaenisch, PND 101-105) mice have reduced capacitance (pF) and dopamine current density (pA/pF). $\boldsymbol{A}$, Capacitance of dopamine neurons in Mecp2 $2^{-1 y}$ mice was significantly less than that in wild type. $\boldsymbol{B}$, The dopamine current density was significantly reduced in the Mecp $2^{-/ y}$ mice. Mean \pm SEM; asterisk $\left(^{*}\right)$ designates statistical significance.

Blasi and Mennini, 1982; O'Boyle and Waddington, 1984; Henry et al., 1986; Hyttel, 1987; Morelli et al., 1990; Ishibashi et al., 2009), but no change in the substantia nigra (Morelli et al., 1990; De Keyser et al., 1991). In agreement with these reports, the results of the present study indicated that the density of $\mathrm{D}_{2}$ receptors in the mouse striatum decreased with age. Yet, the $D_{2}$ receptor density in midbrain and $\mathrm{D}_{2}$ receptor-activated current density in SN dopamine neurons remained stable with age.

There was a significant decrease in capacitance and number of dendrites of dopamine neurons in wild-type females after 1 month of age. These results indicate that the size of dopamine neurons decreases at a relatively young age likely due, in part, to pruning of dendrites. In addition, the disproportionate increase in resistance of dopamine neurons suggested that there is a decline in the density of open ion channels that contribute to the resting conductance. Taken together, these results are indicative of tight regulation of dopamine transmission in the midbrain despite a developmental decline in cell size and resting conductance.

\section{Cellular defects in Mecp2 ${ }^{-}$neurons detected with respect to presentation of motor symptoms}

In both wild-type and Mecp $2^{+/-}$mice there was a developmental decline in membrane surface area of dopamine cells. Despite this, the morphology of $\mathrm{HET}^{+}$and WT neurons was indistinguishable in young and adult mice. Moreover, there was no difference in the resting conductance or dopamine current density between $\mathrm{HET}^{+}$and WT neurons at both ages. Thus, the expression of Mecp2 in dopamine neurons is sufficient to develop and maintain wild-type morphology and function, whereas the loss of Mecp2 results in altered development and maintenance of morphology and function.

Consistent with a previous report in locus coeruleus (LC) neurons from presymptomatic Mecp $2^{+/-}$mice (Taneja et al., 2009), the present study shows that as early as 4 weeks of age the capacitance of $\mathrm{HET}^{-}$dopamine neurons from Mecp2 $2^{+/-}$mice was less than that of $\mathrm{HET}^{+}$and WT neurons. The decrease in membrane surface area is consistent with the smaller soma area reported previously for Mecp $2^{-} \mathrm{SN}$ dopamine neurons from Mecp $2^{-/ y}$ mice (Panayotis et al., 2011). Additionally, $\mathrm{HET}^{-}$neurons had fewer dendrites, contributing to the reduced capacitance measurements. As was found in $\mathrm{HET}^{-}$LC neurons, the resting conductance of $\mathrm{HET}^{-}$dopamine neurons was also less than that of wild-type females. Thus, the cellular consequences of Mecp2 loss occur several months before the manifestation of any obvious motor symptoms.

After the development of motor symptoms, the reduced capacitance, dendritic arbor, and resting conductance observed in $\mathrm{HET}^{-}$neurons persisted. Additional cellular defects were observed only in $\mathrm{HET}^{-}$neurons from symptomatic Mecp $2^{+/-}$ mice, including a significant decrease in the $\mathrm{D}_{2}$ receptoractivated current density. The attenuated response to dopamine in $\mathrm{HET}^{-}$neurons could be due to a specific decrease in midbrain $\mathrm{D}_{2}$ autoreceptors. However, saturation binding analyses indicated that the $\mathrm{D}_{2}$ receptor density and affinity for $\left[{ }^{3} \mathrm{H}\right] \mathrm{YM}$ 09151-2 in midbrain of Mecp $2^{+/-}$mice was indistinguishable from those in wild-type mice. Given that these experiments were performed on tissue homogenates from $M e c p 2^{+/-}$mice, it is possible that the $\mathrm{D}_{2}$ receptor density of $\mathrm{HET}^{+}$neurons may have obscured a decrease in $\mathrm{D}_{2}$ receptor density specific to $\mathrm{HET}^{-}$ neurons. Additionally, these experiments do not preclude dysfunction in $\mathrm{D}_{2}$ receptor trafficking to the plasma membrane. The attenuated response to dopamine could be due to a change in the coupling of $\mathrm{D}_{2}$ receptors to the GIRK channel. It is possible the higher efficacy with which $\mathrm{GABA}_{\mathrm{B}}$ receptors activate GIRK conductance obscures observation of significant perturbation in $\mathrm{GABA}_{\mathrm{B}}$ receptor-mediated current density. These results suggest that a specific consequence of Mecp2 loss is a progressive decline in the normal regulation of dopamine neurons, coinciding with motor behavior disturbances.

\section{No detrimental effect of Mecp2 ${ }^{-}$cells on Mecp2 ${ }^{+}$dopamine neurons}

Studies aimed at addressing the interplay between Mecp ${ }^{+}$and Mecp $2^{-}$cells have produced mixed results, supporting cell autonomous as well as non-cell autonomous consequences of Mecp2 mutation on neuronal morphology and function that may be region specific (Belichenko et al., 2009; Kishi and Macklis, 2010). In this study, Mecp $2^{+}$dopamine neurons from Mecp $2^{+/-}$ mice were indistinguishable from wild-type dopamine neurons in morphology, conductance, and current induced by dopamine. This finding is consistent with reports that $\mathrm{HET}^{+} \mathrm{LC}$ neurons are 
no different in size and conductance than wild-type neurons (Taneja et al., 2009).Together, this study indicates that the loss of Mecp2 in surrounding cells, including neurons and glia, did not affect Mecp $2^{+}$dopamine neurons in a detrimental manner.

Can the presence of Mecp2 ${ }^{+}$cells affect Mecp2 ${ }^{-}$neurons in a beneficial manner? The resting conductance and dopamine current density in Mecp2 ${ }^{-}$dopamine neurons from young $M e c p 2^{+/-}$females and $M e c p 2^{-/ y}$ males were comparable. Thus, it is unlikely that Mecp2 ${ }^{+}$cells have influenced resting conductance and $\mathrm{D}_{2}$ receptor signaling in Mecp2 ${ }^{-}$neurons. However, the comparison between young $M e c p 2^{+/-}$females and Mecp $2^{-/ y}$ males suggested that Mecp2 ${ }^{-}$neurons in the males were more affected in terms of capacitance. Consistent with this, Belichenko et al. (2009) reported that the severity of some dendritic abnormalities in Mecp2 ${ }^{-}$cortical neurons were greater in Mecp2 $2^{-/ y}$ males than in $\operatorname{Mecp}^{+/-}$females. It is possible that the declining health of the Mecp $2^{-/ y}$ males, symptomatic by 3 weeks of age (Guy et al., 2001; Belichenko et al., 2009), brought about the more severe morphological defects observed. Alternatively, it is possible that a cell-autonomous consequence of Mecp2 loss is rendering the development and maintenance of morphology more vulnerable to environmental influences. The maintained expression of Mecp2 in some cells may offer partial support or protection to Mecp2 ${ }^{-}$neurons. These findings illustrate the importance of investigating the outcome of heterogeneous Mecp2 expression, as the mosaic pattern of Mecp2 expression is an important aspect in the genetic model of RTT.

\section{Compromised nigrostriatal pathway in adult Mecp2 ${ }^{+/-}$mice coincides with motor deficits}

Dopamine transmission in the midbrain is thought to contribute to learning, movement, and reward processing, as well as to a variety of neurological diseases. The motor deficits in Rett syndrome have been compared to those in Parkinson's disease (FitzGerald et al., 1990; Wenk et al., 1991), which results from the progressive degeneration of dopamine neurons in the substantia nigra. However, motor deficits have been shown to occur through disruption of dopamine transmission without degeneration in a mouse model for Parkinson's disease, where striatal dopamine content is reduced without dopamine cell death in the substantia nigra (Colebrooke et al., 2006). In the present study, less dopamine was released in the dorsal striatum in symptomatic Mecp $2^{+/-}$mice. This is consistent with a previous report of reduced striatal dopamine levels in Mecp $2^{-1 y}$ males that exhibit motor deficits (Panayotis et al., 2011).

Activation of $\mathrm{D}_{2}$ autoreceptors inhibits terminal release of dopamine (Phillips et al., 2002). The present study identified a decrease in $\mathrm{D}_{2}$ autoreceptor-mediated currents in symptomatic $M e c p 2^{+/-}$and $M e c p 2^{-1 y}$ mice. These results are seemingly inconsistent with the reduced release of dopamine in the dorsal striatum measured electrochemically in $\mathrm{Mecp}^{+/-}$mice. However, given that a single stimulation was used to evoke release, $D_{2}$ autoreceptor activation did not contribute to these measurements. Thus, the reduced dopamine level in striatum may be a consequence of fewer axon terminals or reduced dopamine synthesis. Conditional loss of Mecp2 in catecholamine neurons has been shown to reduce dopamine synthesis and results in motor impairments (Samaco et al., 2009).Together, dysfunction in terminal dopamine release and $\mathrm{D}_{2}$ autoreceptor-dependent currents in dopamine neurons indicated that heterogeneous loss of Mecp2 compromises healthy functioning of the nigrostriatal pathway.

In summary, the present study identified morphological and functional consequences of loss of Mecp2 in SN dopamine neurons. Mutation in Mecp2 in Mecp2 $2^{+/-}$mice led to cellautonomous cellular changes in the $\mathrm{SN}$, some occurring months before and others coinciding with the appearance of motor symptoms. It should be noted that, as described previously (Taneja et al., 2009), this study defines cell-autonomous as mechanisms that are strictly dependent on whether a cell expresses Mecp2. In this study, alterations were observed exclusively in Mecp $2^{-}$neurons, while Mecp $2^{+}$dopamine neurons were indistinguishable from neurons of wild-type females. The results support the idea that decreased dopamine transmission due to heterogeneous Mecp2 loss contributes to the parkinsonian features of RTT in $M e c p 2^{+/-}$ mice. Ultimately, mutation in Mecp2 compromises healthy functioning of the nigrostriatal pathway and supports the manifestation of motor deficits.

\section{References}

Bath BD, Michael DJ, Trafton BJ, Joseph JD, Runnels PL, Wightman RM (2000) Subsecond adsorption and desorption of dopamine at carbonfiber microelectrodes. Anal Chem 72:5994-6002.

Beckstead MJ, Grandy DK, Wickman K, Williams JT (2004) Vesicular dopamine release elicits an inhibitory postsynaptic current in midbrain dopamine neurons. Neuron 42:939-946.

Beckstead MJ, Gantz SC, Ford CP, Stenzel-Poore MP, Phillips PE, Mark GP, Williams JT (2009) CRF enhancement of GIRK channel-mediated transmission in dopamine neurons. Neuropsychopharmacology 34:1926-1935.

Belichenko NP, Belichenko PV, Mobley WC (2009) Evidence for both neuronal cell autonomous and nonautonomous effects of methyl-CpGbinding protein 2 in the cerebral cortex of female mice with Mecp2 mutation. Neurobiol Dis 34:71-77.

Chahrour M, Zoghbi HY (2007) The story of Rett syndrome: from clinic to neurobiology. Neuron 56:422-437.

Chen RZ, Akbarian S, Tudor M, Jaenisch R (2001) Deficiency of methylCpG binding protein-2 in CNS neurons results in a Rett-like phenotype in mice. Nat Genet 27:327-331.

Colebrooke RE, Humby T, Lynch PJ, McGowan DP, Xia J, Emson PC (2006) Age-related decline in striatal dopamine content and motor performance occurs in the absence of nigral cell loss in a genetic mouse model of Parkinson's disease. Eur J Neurosci 24:2622-2630.

De Blasi A, Mennini T (1982) Selective reduction of one class of dopamine receptor binding sites in the corpus striatum of aged rats. Brain Res 242:361-364.

De Keyser J, De Backer JP, Vauquelin G, Ebinger G (1991) $D_{1}$ and $D_{2}$ dopamine receptors in human substantia nigra: localization and the effect of aging. J Neurochem 56:1130-1133.

Dunn HG, MacLeod PM (2001) Rett syndrome: review of biological abnormalities. Can J Neurol Sci 28:16-29.

FitzGerald PM, Jankovic J, Percy AK (1990) Rett syndrome and associated movement disorders. Mov Disord 5:195-202.

Ford CP, Gantz SC, Phillips PE, Williams JT (2010) Control of extracellular dopamine at dendrite and axon terminals. J Neurosci 30:6975-6983.

Guy J, Hendrich B, Holmes M, Martin JE, Bird A (2001) A mouse Mecp2null mutation causes neurological symptoms that mimic Rett syndrome. Nat Genet 27:322-326.

Guy J, Gan J, Selfridge J, Cobb S, Bird A (2007) Reversal of neurological defects in mouse model of Rett syndrome. Science 315:1143-1147.

Hagberg B (1985) Rett's syndrome: prevalence and impact on progressive severe mental retardation in girls. Acta Paediatr Scand 74:405-408.

Henry JM, Filburn CR, Joseph JA, Roth GS (1986) Effect of aging on striatal dopamine receptor subtypes in Wistar rats. Neurobiol Aging 7:357-361.

Hyttel J (1987) Age related decrease in the density of dopamine $D_{1}$ and $D_{2}$ receptors in corpus striatum of rats. Pharmacol Toxicol 61:126-129.

Ishibashi K, Ishii K, Oda K, Kawasaki K, Mizusawa H, Ishiwata K (2009) Regional analysis of age-related decline in dopamine transporters and dopamine $\mathrm{D}_{2}$-like receptors in human striatum. Synapse 63:282-290.

Kishi N, Macklis JD (2010) MeCP2 functions largely cell-autonomously, but also non-cell-autonomously, in neuronal maturation and dendritic arborization of cortical pyramidal neurons. Exp Neurol 222:51-58.

Koyrakh L, Luján R, Colón J, Karschin C, Kurachi Y, Karschin A, Wickman K (2005) Molecular and cellular diversity of neuronal G-protein-gated potassium channels. J Neurosci 25:11468-11478. 
Laurvick CL, de Klerk N, Bower C, Christodoulou J, Ravine D, Ellaway C, Williamson S, Leonard H (2006) Rett syndrome in Australia: a review of the epidemiology. J Pediatr 148:347-352.

McGill BE, Bundle SF, Yaylaoglu MB, Carson JP, Thaller C, Zoghbi HY (2006) Enhanced anxiety and stress-induced corticosterone release are associated with increased Crh expression in a mouse model of Rett syndrome. Proc Natl Acad Sci U S A 103:18267-18272.

Miralvès J, Magdeleine E, Joly E (2007) Design of an improved set of oligonucleotide primers for genotyping MeCP2tm1.1BirdKO mice by PCR. Mol Neurodegener 2:16.

Morelli M, Mennini T, Cagnotto A, Toffano G, Di Chiara G (1990) Quantitative autoradiographical analysis of the age-related modulation of central dopamine $D_{1}$ and $D_{2}$ receptors. Neuroscience 36:403-410.

Neul JL, Fang P, Barrish J, Lane J, Caeg EB, Smith EO, Zoghbi H, Percy A, Glaze DG (2008) Specific mutations in methyl-CpG-binding protein 2 confer different severity in Rett syndrome. Neurology 70:1313-1321.

O'Boyle KM, Waddington JL (1984) Loss of rat striatal dopamine receptors with ageing is selective for D-2 but not D-1 sites: association with increased non-specific binding of the D-1 ligand $\left[{ }^{3} \mathrm{H}\right]$ piflutixol. Eur J Pharmacol 105:171-174.

Panayotis N, Pratte M, Borges-Correia A, Ghata A, Villard L, Roux JC (2011) Morphological and functional alterations in the substantia nigra pars compacta of the Mecp2-null mouse. Neurobiol Dis 41:385-397.

Phillips PE, Hancock PJ, Stamford JA (2002) Time window of autoreceptormediated inhibition of limbic and striatal dopamine release. Synapse 44:15-22.

Samaco RC, Mandel-Brehm C, Chao HT, Ward CS, Fyffe-Maricich SL, Ren J,
Hyland K, Thaller C, Maricich SM, Humphreys P, Greer JJ, Percy A, Glaze DG, Zoghbi HY, Neul JL (2009) Loss of Mecp2 in aminergic neurons causes cell-autonomous defects in neurotransmitter synthesis and specific behavioral abnormalities. Proc Natl Acad Sci U S A 106:21966-21971.

Schanen NC (1999) Molecular approaches to the Rett syndrome gene. J Child Neurol 14:806-814.

Severson JA, Finch CE (1980) Reduced dopaminergic binding during aging in the rodent striatum. Brain Res 192:147-162.

Shahbazian M, Young J, Yuva-Paylor L, Spencer C, Antalffy B, Noebels J, Armstrong D, Paylor R, Zoghbi H (2002) Mice with truncated Mecp2 recapitulate many Rett syndrome features and display hyperacetylation of histone H3. Neuron 35:243-254.

Taneja P, Ogier M, Brooks-Harris G, Schmid DA, Katz DM, Nelson SB (2009) Pathophysiology of locus ceruleus neurons in a mouse model of Rett syndrome. J Neurosci 29:12187-12195.

Terai M, Hidaka K, Nakamura Y (1989) Comparison of [ $\left.{ }^{3} \mathrm{H}\right] \mathrm{YM}-09151-2$ with $\left[{ }^{3} \mathrm{H}\right]$ spiperone and $\left.\left[{ }^{3} \mathrm{H}\right]\right]$ raclopride for dopamine D-2 receptor binding to rat striatum. Eur J Pharmacol 173:177-182.

Viemari JC, Roux JC, Tryba AK, Saywell V, Burnet H, Peña F, Zanella S, Bévengut M, Barthelemy-Requin M, Herzing LB, Moncla A, Mancini J, Ramirez JM, Villard L, Hilaire G (2005) Mecp2 deficiency disrupts norepinephrine and respiratory systems in mice. J Neurosci 25:11521-11530.

Wenk GL, Naidu S, Casanova MF, Kitt CA, Moser H (1991) Altered neurochemical markers in Rett's syndrome. Neurology 41:1753-1756.

Williams JT, North RA, Shefner SA, Nishi S, Egan TM (1984) Membrane properties of rat locus coeruleus neurones. Neuroscience 13:137-156. 